\title{
Seasonal changes in plasma progesterone concentrations in buffalo cows (Bubalus bubalis)*
}

\author{
L. V. Rao and R. S. Pandey \\ Hormone Research Laboratory, Dairy Chemistry Division, National Dairy Research Institute, \\ Karnal 132001, India
}

\begin{abstract}
Summary. Blood samples were taken from 6 non-inseminated cyclic buffaloes for 1 calendar year. Plasma progesterone concentrations on the day of oestrus and also in the luteal phase of the cycle were significantly higher $(P<0.01)$ in the cooler (warm and cold) seasons than in the hot and dry and hot and humid seasons.
\end{abstract}

\section{Introduction}

Seasonal reproduction is a common device whereby animals respond to climatic extremes which may be detrimental to the survival of the offspring and possibly even to the adults. India is a tropical country and in the north extreme climatic conditions prevail. In summer temperatures reach $42^{\circ} \mathrm{C}$ during the day and $30^{\circ} \mathrm{C}$ during the night. Daylength goes up to $13-14 \mathrm{~h}$. Karnal is situated at $245 \mathrm{~m}$ above mean sea level on $29^{\circ} 43^{\prime} \mathrm{N}$ latitude and $76^{\circ} 58^{\prime} \mathrm{E}$ longitude. Seasonality in buffalo breeding has been reported by many workers (Rife, 1959; Bhattacharya, Luktuke \& Roy, 1970; Roy, Bhattacharya \& Luktuke, 1972). Luktuke, Bhattacharya, Singh \& Khan (1973) found that buffalo ovaries were least active during extreme climatic conditions. The important seasonal reproductive problems are weak or silent oestrus, irregular oestrous cycle lengths, low conception rates and early embryonic mortality.

The mechanisms whereby biometeorological cues are transduced into the endocrine messages that govern gonadal functions are not clearly understood. There are controversial reports regarding the variations of progesterone secretion in dairy cows in natural climatic conditions (Roussel, Beatty \& Lee, 1977; Rosenberg, Herz, Davidson \& Folman, 1977). However, none of these workers followed the same animals throughout the year, and the sampling frequency was low. The present study was undertaken to investigate circannual changes of progesterone concentrations in buffalo.

\section{Materials and Methods}

\section{Animals and blood collection}

Six normally cyclic Murrah buffaloes (2nd lactation) were selected from the Institute herd and they were not inseminated for 1 complete calendar year. They were fed daily Berseem, maize, lucerne and concentrate mixture to provide $365 \mathrm{~g}$ digestible crude protein, $4.54 \mathrm{~kg}$ total digestible nutrient, $7.52 \mathrm{~g}$ crude protein and $8.60 \mathrm{~kg}$ dry matter $/ 500 \mathrm{~kg}$ body weight. The animals were kept in a loose housing system and the occurrence of oestrus was checked 3 times a day by means of a vasectomized bull and behavioural symptoms. The day of oestrus was

* Reprint requests to Professor R. S. Pandey. 
designated Day 0. Blood samples were collected on alternate days via jugular venepuncture into tubes packed in ice. The blood was centrifuged at $4^{\circ} \mathrm{C}$ within $1 \mathrm{~h}$ of collection and plasma was stored at $-20^{\circ} \mathrm{C}$ until analysis.

\section{Experimental conditions}

The months were grouped into four seasons (hot and dry, hot and humid, warm, and cold) in relation to the basic differences in the average maximum temperature and relative humidity. Climatic data are shown in Table 1. The animals were periodically checked for any clinical abnormalities.

Duncan's multiple range test was used for statistical analysis of the data.

Table 1. Average monthly environmental variables throughout the calendar year

\begin{tabular}{|c|c|c|c|c|c|c|c|c|c|c|c|c|}
\hline & \multicolumn{3}{|c|}{ Hot dry } & \multicolumn{3}{|c|}{ Hot humid } & \multicolumn{3}{|c|}{ Warm } & \multicolumn{3}{|c|}{ Cold } \\
\hline & April & May & June & July & Aug. & Sept. & Oct. & Nov. & Dec. & Jan. & Feb. & March \\
\hline $\begin{array}{l}\text { Average temperature } \\
\text { mean }\left({ }^{\circ} \mathrm{C}\right)\end{array}$ & 28 & $32 \cdot 6$ & 31.5 & $29 \cdot 2$ & $29 \cdot 5$ & 28 & 25 & $24 \cdot 5$ & $14 \cdot 7$ & $13 \cdot 6$ & 16 & 19 \\
\hline $\begin{array}{l}\text { Average minimum } \\
\text { temperature }\left({ }^{\circ} \mathrm{C}\right)\end{array}$ & 18.7 & 24.4 & 25.9 & $25 \cdot 7$ & $25 \cdot 5$ & 22.9 & $18 \cdot 1$ & $12 \cdot 1$ & 8.0 & $8 \cdot 1$ & 8.9 & 11.7 \\
\hline $\begin{array}{l}\text { Average maximum } \\
\text { temperature }\left({ }^{\circ} \mathrm{C}\right)\end{array}$ & $37 \cdot 3$ & $40 \cdot 9$ & $37 \cdot 1$ & $32 \cdot 6$ & $33 \cdot 5$ & $33 \cdot 2$ & 31.9 & $27 \cdot 0$ & $21 \cdot 5$ & $19 \cdot 2$ & $23 \cdot 1$ & $26 \cdot 4$ \\
\hline Relative humidity (\%) & 55 & 41 & 72 & 90 & 89 & 89 & 88 & 89 & 91 & 94 & 86 & 85 \\
\hline Rainfall (mm) & $2 \cdot 8$ & 1.0 & 125.8 & 487.8 & $67 \cdot 8$ & 118.4 & $12 \cdot 0$ & $7 \cdot 8$ & 53.8 & $41 \cdot 2$ & $2 \cdot 4$ & $19 \cdot 8$ \\
\hline Wind velocity $(\mathrm{km} / \mathrm{h})$ & $6 \cdot 1$ & $7 \cdot 5$ & $10 \cdot 5$ & 7.5 & 4.4 & 3.7 & $3 \cdot 6$ & $3 \cdot 2$ & 3.9 & 4.9 & $6 \cdot 3$ & $5 \cdot 3$ \\
\hline Sunshine (h) & 11.7 & 10 & $10 \cdot 4$ & $6 \cdot 3$ & 8.4 & $10 \cdot 1$ & 9.4 & $8 \cdot 4$ & $7 \cdot 1$ & $7 \cdot 2$ & $8 \cdot 2$ & 8.4 \\
\hline
\end{tabular}

\section{Radioimmunoassay}

Plasma progesterone concentrations were determined by the radioimmunoassay described by Arora, Bachlaus, Prasad \& Pandey (1979). The antiserum was raised in a rabbit to carboxymethyl progesterone- $7 \alpha-\mathrm{BSA}$. The accuracy was assessed by 8 duplicate estimations of $0.25,0.5,1.0,2.0 \mathrm{ng}$ progesterone added to hormone-free plasma $(0.2 \mathrm{ml})$, and the recoveries were $0.27 \pm 0.01,0.56 \pm 0.03,1.08 \pm 0.03$ and $2.04 \pm 0.04 \mathrm{ng}$ respectively. The sensitivity of the assay was $12.59 \mathrm{pg} /$ tube and was calculated from the smallest amount of standard that was significantly different from zero dose at the $95 \%$ confidence limit. Intra- and inter-assay coefficients of variation were $11.2 \%(n=16)$ and $14.8 \%(n=8)$ respectively. The antiserum cross-reacted $7 \%$ with $3 \beta$-hydroxy-5-pregnane-20-one, $6 \%$ with $11 \alpha$-hydroxy-4-pregnane3,20 -dione, $0.3 \%$ with 17 -hydroxyprogesterone and $<0.2 \%$ with corticosterone, cortisone, cortisol, testosterone and oestradiol-17 $\beta$.

\section{Results}

The progesterone values throughout the oestrous cycle in the four seasons are shown in Table 2.

In each season the progesterone changes throughout the cycle followed the normal pattern reaching maximum values on Day 18 . However, progesterone concentrations were higher on the day of oestrus, and during the luteal phase of the cycle in the warm and cold seasons (Table 3). 
Table 2. Circannual changes of plasma progesterone concentrations $(\mathrm{ng} / \mathrm{ml})$ in buffalo cows during the oestrous cycle

\begin{tabular}{|c|c|c|c|c|c|c|c|c|}
\hline \multirow[b]{2}{*}{$\begin{array}{l}\text { Day } \\
\text { of } \\
\text { cycle }\end{array}$} & \multicolumn{2}{|c|}{ Hot and dry } & \multicolumn{2}{|c|}{ Hot and humid } & \multicolumn{2}{|c|}{ Warm } & \multicolumn{2}{|c|}{ Cold } \\
\hline & $\begin{array}{l}\text { No. of } \\
\text { obser- } \\
\text { vations }\end{array}$ & $\begin{array}{c}\text { Mean } \\
\pm \\
\text { s.e.m. }\end{array}$ & $\begin{array}{l}\text { No. of } \\
\text { obser- } \\
\text { vations }\end{array}$ & $\begin{array}{c}\text { Mean } \\
\pm \\
\text { s.e.m. }\end{array}$ & $\begin{array}{l}\text { No. of } \\
\text { obser- } \\
\text { vations }\end{array}$ & $\begin{array}{c}\text { Mean } \\
\pm \\
\text { s.e.m. }\end{array}$ & $\begin{array}{l}\text { No. of } \\
\text { obser- } \\
\text { vations }\end{array}$ & $\begin{array}{c}\text { Mean } \\
\pm \\
\text { s.e.m. }\end{array}$ \\
\hline 0 & 9 & $0.14 \pm 0.05$ & 19 & $0.16 \pm 0.04$ & 14 & $0.44 \pm 0.09$ & 14 & $0.49 \pm 0.06$ \\
\hline 2 & 15 & $0.27 \pm 0.05$ & 19 & $0.77 \pm 0.11$ & 16 & $0.74 \pm 0.08$ & 11 & $0.96 \pm 0.19$ \\
\hline 4 & 14 & $0.95 \pm 0.03$ & 20 & $0.83+0.09$ & 16 & $0.96 \pm 0.09$ & 12 & $1.28 \pm 0.15$ \\
\hline 6 & 16 & $0.96 \pm 0.12$ & 17 & $0.91 \pm 0.09$ & 16 & $1.47 \pm 0.23$ & 11 & $1.74 \pm 0.20$ \\
\hline 8 & 16 & $1.07 \pm 0.09$ & 18 & $0.98 \pm 0.16$ & 13 & $1.73 \pm 0.41$ & 12 & $1.97 \pm 0.22$ \\
\hline 10 & 14 & $1.23 \pm 0.13$ & 18 & $1.16 \pm 0.10$ & 14 & $1.99 \pm 0.37$ & 10 & $2.06 \pm 0.69$ \\
\hline 12 & 11 & $1.24 \pm 0.31$ & 17 & $1.24 \pm 0.18$ & 12 & $2 \cdot 19 \pm 0.30$ & 12 & $2.22 \pm 0.19$ \\
\hline 14 & 13 & $1.44 \pm 0.21$ & 17 & $1.29 \pm 0.18$ & 12 & $2.33 \pm 0.38$ & 11 & $2.54 \pm 0.28$ \\
\hline 16 & 13 & $1.76 \pm 0.17$ & 20 & $1.57 \pm 0.14$ & 11 & $2.45 \pm 0.33$ & 10 & $2.80 \pm 0.57$ \\
\hline 18 & 12 & $2.05 \pm 0 \cdot 16$ & 19 & $1.72 \pm 0.16$ & 11 & $2.67 \pm 0.49$ & 14 & $3 \cdot 11 \pm 0.20$ \\
\hline-3 & 15 & $0.56 \pm 0.10$ & 15 & $0.54 \pm 0.06$ & 12 & $1.22 \pm 0.28$ & 11 & $1.24 \pm 0.31$ \\
\hline-1 & 17 & $0.36 \pm 0.05$ & 18 & $0.27 \pm 0.07$ & 13 & $0.73 \pm 0.09$ & 12 & $0.94 \pm 0.15$ \\
\hline
\end{tabular}

Table 3. Analysis of progesterone concentrations in different seasons

\begin{tabular}{|c|c|c|c|c|c|}
\hline \multirow{2}{*}{$\begin{array}{l}\text { Day } \\
\text { of } \\
\text { cycle }\end{array}$} & \multicolumn{2}{|c|}{ Between seasons } & \multicolumn{3}{|c|}{ Within seasons } \\
\hline & d.f. & MS & d.f. & MS & F \\
\hline 0 & 3 & 0.532 & 52 & 0.054 & $9 \cdot 69^{* *}$ \\
\hline 2 & 3 & 1.19 & 57 & 0.17 & $6.71^{* *}$ \\
\hline 4 & 3 & 0.516 & 58 & 0.14 & $3.67^{*}$ \\
\hline 6 & 3 & $2 \cdot 22$ & 56 & 0.40 & $5 \cdot 48^{* *}$ \\
\hline 8 & 3 & $3 \cdot 39$ & 55 & 0.77 & $4 \cdot 40^{* *}$ \\
\hline 10 & 3 & $3 \cdot 16$ & 52 & 1.42 & $2 \cdot 22$ \\
\hline 12 & 3 & 4.01 & 48 & 0.75 & $5 \cdot 34^{* *}$ \\
\hline 14 & 3 & $5 \cdot 15$ & 49 & 0.88 & $5 \cdot 82^{* *}$ \\
\hline 16 & 3 & 4.34 & 50 & 1.06 & $4.08^{*}$ \\
\hline 18 & 3 & 5.93 & 52 & 0.88 & $6.73^{* *}$ \\
\hline-3 & 3 & $2 \cdot 34$ & 49 & 0.48 & $4.83^{* *}$ \\
\hline-1 & 3 & 1.41 & 56 & 0.11 & $1 \cdot 2$ \\
\hline
\end{tabular}

\section{Discussion}

Progesterone at appropriate levels is essential for the expression of oestrus, to prepare the animals for pregnancy and to maintain the pregnancy once initiated. In the present study we found significantly different progesterone concentrations in the four seasons (Table 3). Preliminary measurements of oestradiol concentrations also showed that values in the hotter months were lower than in cooler months. These observations support the view that expression of oestrus and secretion of $\mathrm{LH}$ require an appropriate balance between oestradiol and progesterone (Karsch, Legan, Ryan \& Foster, 1980). Higher concentrations of progesterone from Day 0 to Day 13 have been demonstrated in animals which conceive than those which do not conceive (cows; Batra, Pahwa, Suri \& Pandey, 1980; buffalo: Batra, Arora, Bachlaus \& Pandey, 1979; Suri, Batra, Pahwa \& Pandey, 1981). The low progesterone level in hotter 
months in comparison to cooler months is probably responsible for the inadequate expression of oestrus and low conception rates in buffaloes (Table 4).

Table 4. Conception rates of contemporary herd mate buffaloes during the different seasons

\begin{tabular}{lcc}
\hline & No. of inseminations & Conception \% \\
\hline Hot and dry & 74 & $22 \cdot 98^{*}$ \\
Hot and humid & 94 & $25 \cdot 11^{*}$ \\
Warm & 201 & $42 \cdot 41$ \\
Cold & 196 & 28.43 \\
\hline
\end{tabular}

- Significantly different from conception rate in cooler months, $P<0.05$ ( $\chi^{2}$ tests).

Mills, Thatcher, Dunlap \& Vincent (1972) and Abilay, Johnson \& Madan (1975) observed increased progesterone secretion during chronic exposure to heat in climatic chamber studies. These studies have been valuable in establishing the basic parameters of the stress but such an application to field conditions is often difficult because of the diurnal variation in ambient temperature, relative humidity and difficulty in controlling other aspects of the animals' environment.

Our results agree with those of Rosenberg et al. (1977) for cows exposed to natural climatic conditions in summer: reduced fertility and lower plasma progesterone concentrations throughout the luteal phase of oestrous cycle were reported. However, Roussel et al. (1977) found a significantly higher level of progesterone (monthly samples) in cows in the hot season and suggested that this was related to the mobilization of body fat, indicated by substantial weight loss. In the present study, we could not find any appreciable decrease in the body weight of the experimental animals.

The effects of each climatic condition separately cannot be distinguished but lower concentrations in the hot and humid season indicate that humidity reinforces the effect of high temperature to suppress progesterone secretion and ultimately lead to reproductive failures in buffaloes.

We are grateful to Dr D. Sundaresan, Director, for providing facilities, Mr S. K. Batra and Mr G. S. Pahwa for assistance and C.S.S.R.I., Karnal for weather observations. The progesterone antiserum was a generous gift from Dr Bernard Desfoses, UER-BD, Paris. The work is part of a Ph.D. thesis of L.V.R.

\section{References}

Abilay, T.A., Johnson, H.D. \& Madan, M. (1975) Influence of environmental heat on peripheral plasma progesterone and cortisol during the bovine estrous cycle. J. Dairy Sci. 58, 1836-1840.

Arora, R.C., Bachlaus, N.K., Prasad, A. \& Pandey, R.S. (1979) Plasma progesterone level and early pregnancy diagnosis in buffalo heifers. Ind. J. exp. Biol. 17, 124-127.

Batra, S.K., Arora, R.C., Bachlaus, N.K. \& Pandey, R.S. (1979) Blood and milk progesterone in pregnant and non-pregnant buffaloes. J. Dairy Sci. 62, 1390-1393.
Batra, S.K., Pahwa, G.S., Suri, A.K. \& Pandey, R.S. (1980) Diurnal variation of progesterone in milk and milk fat of crossbred cows during oestrous cycle and early pregnancy. Anim. Reprod. 31, 127-131.

Bhattacharya, A.R., Luktuke, S.N. \& Roy, D.J. (1970) Incidence of normal and pathological conditions of she-buffalo genitalia in different months. Ind. $J$. Anim. Sci. 40, 425-429.

Karsch, F.J., Legan, S.J., Ryan, K.D. \& Foster, D.L. (1980) Importance of estradiol and progesterone in regulating $\mathrm{LH}$ secretion and estrous behavior during the sheep estrous cycle. Biol. Reprod. 23, 404-413. 
Luktuke, S.N., Bhattacharya, A.R., Singh, S.K. \& Khan, B.U. (1973) Studies on abberations in functional activity of the ovaries in buffaloes. Ind. vet. $J$. 50, 876-881.

Mills, A.G., Thatcher, W.W., Dunlap, S.E. \& Vincent, C.K. (1972) Influence of postbreeding thermal stress on peripheral plasma progestin concentrations in heifers. J. Dairy Sci. 55, 400-401, Abstr.

Rife, D.C. (1959) The Water Buffalo of India and Pakistan. International Cooperation Administration, Washington, D.C.

Rosenberg, M., Herz, Z., Davidson, M. \& Folman, Y. (1977) Seasonal variations in post-partum plasma levels and conception in primiparous and multiparous dairy cows. J. Reprod. Fert. 51, 363-367.
Roussel, J.D., Beatty, J.F. \& Lee, J.A. (1977) Influence of season and reproductive status on peripheral plasma progesterone level in the lactating bovine. Int. J. Biometeor. 21, 85-91.

Roy, D.J., Bhattacharya, A.R. \& Luktuke, S.N. (1972) Oestrus and ovarian activities of buffaloes in different months. Ind. vet. J. 49, 54-60.

Suri, A.K., Batra, S.K., Pahwa, G.S. \& Pandey, R.S. (1981) Diurnal variations of progesterone in milk of pregnant and non-pregnant buffaloes. J. Dairy Res. 48, 503-507. 